\title{
Corrigendum: Editorial: Serotonin and Memory
}

\author{
Alfredo Meneses ${ }^{1 *}$ and Antonella Gasbarri ${ }^{2}$ \\ ${ }^{1}$ Departamento de Farmacobiología, Centro de Investigación y de Estudios Avanzados del Instituto Politécnico Nacional, \\ Mexico City, Mexico, ${ }^{2}$ Department of Applied Clinical and Biotechnologic Sciences, University of L'Aquila, L'Aquila, Italy
}

Keywords: serotonin, neural markers, therapeutic targets, memory, short-term, memory, long-term, memory disorders

\section{OPEN ACCESS}

Edited and reviewed by:

Nicholas M. Barnes,

University of Birmingham, UK

${ }^{\star}$ Correspondence:

Alfredo Meneses

ameneses@msn.com

Specialty section

This article was submitted to

Neuropharmacology,

a section of the journal

Frontiers in Pharmacology

Received: 08 February 2016

Accepted: 09 February 2016

Published: 12 February 2016

Citation:

Meneses A and Gasbarri A (2016)

Corrigendum: Editorial: Serotonin and

Memory. Front. Pharmacol. 7:36.

doi: 10.3389/fphar.2016.00036

\section{A corrigendum on}

Editorial: Serotonin and Memory

by Meneses, A., and Gasbarri, A. (2016) Front. Pharmacol. 7:8. doi: 10.3389/fphar.2016.00008

Due to an oversight, the name of Antonella Gasbarri in the Editorial article was reported as B. Gasbarri, which also rendered the citation of the Editorial article incorrect. This error does not change the scientific conclusions of the article in any way.

The original article was updated.

\section{AUTHOR CONTRIBUTIONS}

Both authors listed have made substantial, direct and intellectual contribution to the work, and approved it for publication.

Conflict of Interest Statement: The authors declare that the research was conducted in the absence of any commercial or financial relationships that could be construed as a potential conflict of interest.

Copyright $(2016$ Meneses and Gasbarri. This is an open-access article distributed under the terms of the Creative Commons Attribution License (CC BY). The use, distribution or reproduction in other forums is permitted, provided the original author(s) or licensor are credited and that the original publication in this journal is cited, in accordance with accepted academic practice. No use, distribution or reproduction is permitted which does not comply with these terms. 